\title{
Perbandingan Pelampung Batang Dan Pelampung Punggung Terhadap Keterampilan Renang Gaya Bebas
}

\section{Comparison of Trunk Buoys and Back Buoys on Freestyle Swimming Skills}

\author{
Sony Hasmarita \\ ${ }^{1}$ Program studiPJKR, STKIP Pasundan, Jalan Permana No. 32B Kota Cimahi, Jawa Barat, \\ 40553, Indonesia
}

\begin{abstract}
Abstrak
Tujuan penelitian ini adalah: (1) Mengetahui pengaruh pelampung batang terhadap keterampilan renang gaya bebas (2) Mengetahui pengaruh pelampung punggung terhadap keterampilan renang gaya bebas (3) Mengetahui manakah yang lebih berpengaruh antara pelampung batang dan pelampung punggung terhadap keterampilan renang gaya bebas di rizky swimming club. Dalam penelitian ini penulis menggunakan metode eksperimen dengan mencobakan sesuatu perlakuan untuk mengetahui seberapa besar pengaruhnya terhadap obyek yang dikenainya. Populasi yang digunakan dalam penelitian ini adalah siswa rizky swimming club yang berjumlah 95 orang siswa, sedangkan sampel yang digunakan adalah 25 orang dari siswa yang belum mahir renang gaya bebas dengan teknik pengambilan sampel menggunakan Sampling purposive. Dari hasil penghitungan terlihat bahwa perbedaan rata-rata antara pre test dan post test terjadi secara signifikan terhadap kelompok eksperimen (pengguna pelampung batang) 32.00 sedangkan rata-rata kelompok kontrol (pengguna pelampung punggung) 34.00 terhadap keterampilan renang gaya bebas. Hasil perhitungan $t$ perbandingan perbedaan dua hasil pembelajaran 2,131 lebih kecil dari t Tabel 2,156. Dengan demikian kita bisa menolak hipotesis (Ho), maka dapat disimpulkan bahwa: Media pelampung punggung lebih memberikan Pengaruh Terhadap keterampilan renang gaya bebas dibandingkan Dengan Pelampung batang. Adapun rekomedasi yang berkaitan oemar hamalik media dapat membangkitkan motivasi dan pengaruh psikologis bagi peserta didik. Ernawan s. media merupakan salah satu sebagai segala bentuk yang di mamfaatkan dalam proses pembelajaran.
\end{abstract}

Kata kunci: Pelampung Batang, Pelampung Punggung, Keterampilan Renang Gaya Bebas

\begin{abstract}
The purpose of this research is: (1) Knowing the influence of rodents on the ability to swim freely (2) Knowing the influence of rodents on the ability to swim freely (3) Knowing which one has a greater impact on free swimming skills in the Risky swimming club. In this study, writers use experimental methods to try something behavioral to figure out how much it affects the object they drive. The population used in this study is a 95-person Risky swimming club student, while the sample used is 25 people from students who are not yet able to swim freely with sampling techniques using Purpose Sampling. It appears from the calculations that the average difference between pre-test and post-test occurs significantly for the experimental group (the stick shelter user) 32.00 while the average control group (the back shelter user) 34.00 for the free swimming skills. The results of the t-comparison compare the differences of two learning outcomes 2,131 smaller than t Table 2,156. So we can reject the hypothesis, so it can be concluded that: the spinal cord media gives the Infantry more free-style swimming skills than with the rodent.
\end{abstract}

Keywords: Bar Buoy, Back Buoy, Freestyle Swimming Skills 



\section{PENDAHULUAN}

Aktivitas aquatic merupakan salah satu kegiatan olahraga yang digemari masyarakat untuk menjaga dan meningkatkan kesehatan. Olahraga renang dapat dilakukan oleh semua usia mulai dari anak-anak, dewasa hingga orang tua. renang adalah salah satu cabang olahraga yang bisa diajarkan pada semua umur, baik itu anak-anak ataupun orang dewasa bahkan bayi yang berumur beberapa bulan juga sudah bisa diajarkan renang (Mukhammadi hamsa, 2015). renang adalah olahraga air yang dilakukan dengan cara menggerakan kaki, tangan, kepala, dan badan saat mengapung dipermukaan air ( Elly puji astutik, 2014). Adapun kemampuan dasar dalam air yang harus dimiliki meliputi: kemampuan mengapung, kemampuan merubah posisi tubuh (telungkup, terlentang, tegak, miring) kemampuan dasar mendayung (maju, mundur, naik, turun) berputar vertical maupun horizontal (Aisya husein, 2012).

Renang merupakan olahraga yang sangat baik untuk kesehatan tubuh karena hampir semua otot dan persendian bergerak ketika berenang. Olahraga renang dapat dilakukan oleh siapa saja baik putra maupun putri, bahkan "renang adalah salah satu cabang olahraga yang bisa diajarkan pada semua umur, baik itu anak-anak maupun orang dewasa, bahkan bayi yang berumur beberapa bulan juga sudah bisa diajarkan renang (Mukhammadi hamsa, 2015). Ada beberapa macam gaya dalam olahraga renang yang diperlombakan diberbagai ajang diantaranya renang gaya bebas, gaya punggung, gaya dada, dan gaya kupu-kupu. Salah satu dari ke empat gaya tersebut ada yang dapat kita pelajari salah satunya yaitu renang gaya punggung.

Media berasal dari bahasa latin yang merupakan bentuk jamak dari "medium", secara harfiah berarti perantara atau pengantar. Association for Education and Communicati on Technology (AECT), mengartikan kata media sebagai segala bentuk dan saluran yang dipergunakan untuk proses informasi. National Education Association (NEA) mendefinisikan media sebagai segala benda yang dapat dimanipulasikan, dilihat, didengar, dibaca atau dibicarakan beserta instrumen yang dipergunakan untuk kegiatan tersebut (Tejo nurseto, 2011). Media pembelajaran dipergunakan untuk memudahkan dalam penyampaian materi kepada peserta didik. Peserta didik akan terbantu dalam memahami materi yang komplek. Pemanfaatan media juga berperan besar dalam memberikan pengalaman belajar peserta didik. Belajar merupakan interaksi antara seseorang dengan orang lain, media, atau dengan lingkungannya. Indikasi adanya perubahan afektif, kognitif, psikomor dan fisik merupakan ciri peserta didik telah belajar dari apa yang diterimanya (Herka Maya Jatmika, 2007).

Dalam kaitannya dengan fungsi media pembelajaran, dapat ditekankan beberapa hal berikut ini: 1. Sebagai sarana bantu untuk mewujudkan situasi pembelajaran yang lebih efektif.2. Sebagai salah satu kompones dalam rangka menciptakan situasi bela. aling berhubungan dengan komponen lainnya diharapkan. 3. Mempercepat proses belajar. 4. 
Meningkatkan kualitas proses belajar-mengajar. 4. Mengkongkritkan yang abstrak sehingga dapat mengurangi terjadinya penyakit verbalisme (Tejo nurseto, 2011).

Salah satu daya apung yang paling populer adalah Pelampung Batang (swimming noodle), adalah contoh silinder busa polythene berdiameter sekitar 3 inci dan panjangnya 58 inci. Salah satu yang paling populer dan banyak mengapung saat pelajaran berenang. Beberapa kali disebut 'woggle' itu murah untuk dibuat, murah untuk dibeli dan mudah digunakan dalam pelajaran renang kelompok besar. Pelampung Batang sangat serbaguna dan karena ini bukan bantuan tetap, bisa digunakan dan dibuang dengan mudah. Ini juga bisa menambah rasa asyik berenang karena bisa diselipkan di bawah lengan di bagian depan dan belakang serta diletakkan di antara kaki dan digunakan sebagai a'horse (Mark Young, 2016). Pelampung punggung merupakan salah satu alat bantu berenang yang bisa digunakan untuk melatih atau mempelajari renang. Alat ini terbuat dari busa/bahan spon/karet super yang anti rembes dan nyaman bisa dipakai untuk anak-anak dan dewasa serta memiliki tingkat daya apung yang lumayan tinggi, pelampung ini berfungsi untuk membantu menopang keseimbangan badan disaat akan mempelajari renang.

Pelampung renang yang dimaksud ini ada dua macam yaitu pelampung batang dan pelampung punggung bentuknya berbeda hanya saja keduanya memiliki fungsi yang sama-sama digunakan sebagai alat untuk mengapung didalam air, namun penulis disini terfikir untuk membandingkan kedua alat tersebut, guna ingin mengetahui mana yang lebih baik untuk digunakan dalam pembelajaran. Berdasarkan hasil penelitian berdasarkan penelitian sebalumnya, dapat diketahui bahwa terdapat perbedaan antara pelampung batang dan pelampung punggung terhadap keterampilan renang gaya punggung. Mean kelompok pelampung punggung lebih besar dari mean kelompok pelampung batang. Dari kedua alat bantu tersebut yang paling efektif, aman dan nyaman adalah pelampung punggung (ujang, 2018). Media dalam olahraga renang ini bermacam-macam, dan media pembelajaran yang akan dipakai dalam pembelajaran renang gaya bebas ini yaitu pelampung yang dipercaya bisa menopang dan membantu proses pembelajaran renang agar tetap bisa mengapung dipermukaan air.

Berdasarkan uraian di atas mulai dari pakta di lapangan dan teori, maka penulis ingin mengetahui seberapa efektif dan efisien mengenai media yang di gunakan dalam pembelajaran renang gaya bebas menggunakan media alat bantu berupa pelampung batang dan pelampung punggung, media atau alat bantu mana yang lebih efektif untuk di gunakan dalam proses pembelajaran renang gaya bebas. 


\section{METODE}

Dalam penelitian ini penulis menggunakan metode eksperimen dengan mencobakan sesuatu perlakuan untuk mengetahui seberapa besar pengaruhnya terhadap obyek yang dikenainya. Adapun pengertian eksperimen itu sendiri yaitu "Eksperimen merupakan metode penelitian yang digunakan untuk mencari pengaruh perlakuan tertentu terhadap yang lain dalam kondisi yang terkendalikan"(sugiono, 2012).

Metode eksperimen yang digunakan penulis dalam penelitian ini adalah eksperimen murni yaitu Pre test - Posttest Control Group Design "sebagimana dalam eksperimen ini terdapat dua kelompok yang dipilih yaitu kelompok eksperimen dan kelompok kontrol yang dipilih secara acak atau random, kemudian di beri pretest untuk mengetahui keadaan awal adakah perbedaan antara kelompok eksperimen dan kelompok kontrol (sugiono, 2014).

Rencana penelitian penelitian ini dilaksanakan sebanyak 12 kali pertemuan yang diantaranya adalah Pretest - Treatment - Post Test. Penentuan lamanya pelaksanaan penelitian ini saya tentukan dari sebuah jurnal (Fx.sugiyanto, 2011). Untuk gambaran singkat nya bisa dilihat pada tabel berikut ini.

Tabel 1. Program perlakuan

\begin{tabular}{|c|c|c|c|c|c|}
\hline Pertemuan & Hari & Waktu & Kegiatan & keterangan & Tempat \\
\hline 1 & $\begin{array}{l}\text { Senin } 15 \\
\text { agustus } 2019\end{array}$ & $2 \times 50$ menit & Pretest & Tes awal & Kolam renang \\
\hline 2 & $\begin{array}{l}\text { Kamis } 21 \\
\text { agustus } 2019\end{array}$ & $2 \times 45$ menit & Perlakuan & Daya apung & Kolam renang \\
\hline 3 & $\begin{array}{l}\text { Senin } 25 \\
\text { agustus } 2019\end{array}$ & $2 \times 45$ menit & Perlakuan & Daya apung & Kolam renang \\
\hline 4 & $\begin{array}{l}\text { Kamis } 28 \\
\text { agustus } 2019\end{array}$ & $2 \times 45$ menit & Perlakuan & $\begin{array}{l}\text { Gerakan kaki } \\
\text { gaya bebas }\end{array}$ & Kolam renang \\
\hline 5 & $\begin{array}{l}\text { Senin } 2 \text { agustus } \\
2019\end{array}$ & $2 \times 45$ menit & Perlakuan & $\begin{array}{l}\text { Gerakan kaki } \\
\text { gaya bebas }\end{array}$ & Kolam renang \\
\hline 6 & $\begin{array}{l}\text { Kamis } 5 \text { agustus } \\
2019\end{array}$ & $2 \times 45$ menit & Perlakuan & $\begin{array}{l}\text { Gerakan tangan } \\
\text { gaya bebas }\end{array}$ & Kolam renang \\
\hline 7 & $\begin{array}{l}\text { Senin } 8 \\
\text { september } 2019\end{array}$ & $2 \times 45$ menit & Perlakuan & $\begin{array}{l}\text { Gerakan tangan } \\
\text { gaya bebas }\end{array}$ & Kolam renang \\
\hline 8 & $\begin{array}{l}\text { Kamis } 11 \\
\text { september } 2019\end{array}$ & $2 \times 45$ menit & 147 & $\begin{array}{l}\text { Gerakan tangan } \\
\text { dan irama nafas } \\
\text { gaya bebas }\end{array}$ & Kolam renang \\
\hline 9 & $\begin{array}{l}\text { Senin } 15 \\
\text { september } 2019\end{array}$ & $2 \times 45$ menit & Perlakuan & $\begin{array}{l}\text { Gerakan tangan } \\
\text { dan irama nafas } \\
\text { gaya bebas }\end{array}$ & Kolam Renang \\
\hline
\end{tabular}




\begin{tabular}{|c|c|c|c|c|c|}
\hline 10 & $\begin{array}{l}\text { Kamis } 18 \\
\text { september } 2019\end{array}$ & $2 \times 45$ menit & Perlakuan & $\begin{array}{l}\text { Gerakan } \\
\text { koordinasi gaya } \\
\text { bebas }\end{array}$ & Kolam renang \\
\hline 11 & $\begin{array}{l}\text { Senin } 23 \\
\text { september } 2019\end{array}$ & $2 \times 45$ menit & Perlakuan & $\begin{array}{l}\text { Gerakan } \\
\text { koordinasi gaya } \\
\text { bebas }\end{array}$ & Kolam renang \\
\hline 12 & $\begin{array}{l}\text { Kamis } 25 \\
\text { september } 2019\end{array}$ & $2 \times 45$ menit & PostTest & Tes Akhir & Kolam renang \\
\hline
\end{tabular}

Populasi yang akan dijadikan sumber data penelitian ini adalah siswa di rizky swimming club dengan jumlah populasi sebanyak 95 orang siswa. Pada penelitian ini peneliti menggunakan partisipan sebanyak 25 orang siswa dari jumlah total populasi sebanyak 95 orang siswa risky swimming club yang rata - rata usia partisipan 8-12 tahun. Dalam penelitian ini peneliti menggunakan teknik sampling purposive, di karenakan pertimbangan - pertimbangan pertama siswa yang sudah terdaftar sebagai siswa tetap. Kedua siswa yang belum mahir renang gaya bebas. Ketiga data partisipan yang bersedia hadir pada hari yang di tentukan peneliti.

Teknik pengumpulan data dalam penelitian ini adalah berupa tes kemampuan (pretest dan posttest) yang berbentuk tes melakukan keterampilan renang gaya bebas. Tes awal (pretest) dilakukan untuk mengetahui kemampuan awal siswa melakukan keterampilan renang gaya bebas sebelum menggunakan pelampung batang dan pelampung punggung. Sedangkan tes akhir (posttest) dilakukan untuk mengetahui kemampuan akhir siswa mengenai keterampilan renang gaya bebas sesudah menggunakan pelampung batang dan pelampung punggung (treatment). Teknik analisis data pada penelitian ini menggunaka microsoft excel. kemudian Mencari nilai rata-rata, Mencari simpangan baku/ standar deviasi, Menguji Normalitas Dengan menggunakan rumus uji Lilifors dan Menguji Homogenitas. Kemudian Menguji hipotesis menggunakan uji kesamaan dua rata-rata (skor berpasangan) Setelah menggunakan uji normalitas, maka untuk menguji hipotesis dilakukan dengan uji t.

\section{HASIL DAN PEMBAHASAN}

\section{Hasil}

Setelah data diperoleh, kemudian data tersebut diolah dengan menggunakan rumus yang telah dikemukakan. Pengolahan dilakukan agar data yang diperoleh mengandung makna bagi penelitian. Adapun langkah-langkah yang ditempuh dalam pengolahan data sebagai berikut:

\section{Menghitung Rata-Rata Dan Simpangan Baku}


Hasil penghitungan rata-rata dan simpangan baku kelompok pelampung batang terdapat tes awal sebesar 32.929, tes akhir sebesar 34.215. Sedangkan simpangan baku tes awal sebesar 3.626, tes akhir sebesar 3.215 Untuk menguji data tersebut, harus diuji dengan pendekatan uji t dan data berdistribusi normal.

Hasil Penghitungan Rata-Rata Dan Simpangan Baku Kelompok Pelampung Punggung terdapat tes awal sebesar 32.714, tes akhir sebesar 34.000. Sedangkan simpangan baku tes awal sebesar 4.027, tes akhir sebesar 3.464 Untuk menguji data tersebut, harus diuji dengan pendekatan uji t dan data berdistribusi normal.

\section{Uji Normalitas}

Hasil Penghitungan Uji Normalitas Kelompok Pelampung Batang dapat dikemukakan dari tes awal diperoleh Lo hitung sebesar 32.929, tes akhir sebesar 34.215. selanjutnya dibandingkan dengan L-tabel (0,05: 14) sebesar 3.626. berarti Lo hitung lebih besar dari pada Ltabel, dengan demikian dapat dikemukakan bahwa distribusi data tersebut adalah Normal.

Hasil Penghitungan Uji Normalitas Kelompok Pelampung punggung dapat dikemukakan dari tes awal diperoleh Lo hitung sebesar 0,111, tes akhir sebesar 0,117. Selanjutnya dibandingkan dengan L tabel $(0,05: 14)$ sebesar 0,227 . Berarti Lo hitung lebih kecil dari pada L-tabel, dengan demikian dapat dikemukakan bahwa distribusi data tersebut adalah Normal.

\section{Uji Homogenitas}

Dari hasil pengujian homognitas kelompok pelampung batang diketahui nilai $\mathrm{F}$ hitung $(1,347)<$ F tabel (2.55) dengan besarnya $\alpha=0,05 \mathrm{dan} \mathrm{dk}$ (13: 13), sehingga dapat disimpulkan bahwa penggunaan pelampung batang sebagai kelompok eksperimen dalam penelitian perbandingan pelampung batang dan pelampung punggung terhadap keterampilan renang gaya bebas, dari pelaksanaan tes awal dan tes akhir tersebut hasilnya Homogen.

Dari hasil pengujian homognitas kelompok pelampung punggung diketahui nilai $f$ hitung $(1,020)<\mathrm{f}$ tabel (2.55) dengan besarnya $\alpha=0,05 \mathrm{dan} \mathrm{dk}(14: 14)$, sehingga dapat disimpulkan bahwa pelampung punggung sebagai kelompok eksperimen pada penelitian yang berjudul perbandingan pelampung punggung terhadap keterampilan renang gaya bebas, dari pelaksanaan tes awal dan tes akhir tersebut hasilnya homogen.

\section{Uji Hipotesis Menggunakan Uji Kesamaan Dua Rata-Rata (Skor Berpasangan )}

Dari hasil penghitungan dan analisis data diperoleh $\mathrm{T}$ hitung pelampung batang sebesar 6.687, selanjutnya dibandingkan dengan $\mathrm{T}$ tabel $0,05(13)=2,160$ harga $t$ hitung lebih besar dari pada $\mathrm{t}$ tabel, dan $\mathrm{t}$ hitung berada diluar daerah penerimaan hipotesis,pelampung batang berpengaruh signifikan terhadap keterampilan renang gaya bebas, begitu juga dengan pelampung punggung berpengaruh signifikan dengan hasil perhitungan sebesar 5.071 yang 
berarti harga t hitung lebih besar dari pada $t$ tabel,dan $t$ hitung berada diluar daerah penerimaan hipotesis.

\section{Uji Hipotesis Menggunakan Uji Kesamaan Dua Rata-Rata (Dua Pihak)}

Tabel 2

Hasil penghitungan uji hipotesis kesamaan dua rata-rata (dua pihak) pelampung batang dan pelampung punggung

\begin{tabular}{llllll}
\hline Kelompok & Rata-rata & Simpangan & T & t Tabel & Hasil \\
\cline { 2 - 5 } & $(\mathbf{X B})$ & Baku (SBb) & Hitung & $\mathbf{0 , 0 5}(\mathbf{2 8})$ & \\
\hline $\begin{array}{l}\text { Kelompok } \\
\text { Kontrol }\end{array}$ & 0,4 & 1,18 & 2,131 & 2,158 & Signifikan \\
& & & & & \\
Kelompok & 0,8 & & & & \\
Eksperimen & & & & & \\
\end{tabular}

Kriteria penerimaan dan penolakan hipotesisnya (Ho): Terima hipotesis jika $-\frac{w_{1} t_{1}+w_{2} t_{2}}{w_{1}+w_{2}}<t^{1}<\frac{w_{1} t_{1}+w_{2} t_{2}}{w_{1}+w_{2}}$

Oleh karena t, $(2,131)$ berada diantara $-2,158$, maka hipotesis Ho diterima. Hal ini menunjukan bahwa nilai $\mathrm{t}(2,131)$ berada pada daerah penerimaan hipotesis. Dengan demikian dapat disimpulkan bahwa media pelampung punggung lebih berpengaruh terhadap keterampilan renang gaya bebas.

\section{Pembahasan}

Pelampung batang dan pelampung punggung merupakan media pembelajaran aquatic yang sering terlibat dalam pembelajaran olahraga renang kedua alat tersebut sangat membantu siswa dan mendukung pengajar atau pelatih untuk memudahkan proses pembelajaran. dalam pembelajaran renang gaya bebas menggunakan pelampung batang dan pelampung punggung siswa dikelompokan menjadi 2 yaitu kelompok A (pelampung batang) dan kelompok B (pelampung punggung).

Pada saat penelitian dilapangan diketahui bahwa penggunaan pelampung punggung yang diberikan pada kelompok B berdampak lebih baik dibandingkan dengan kelompok A yang menggunakan pelampung batang, selain itu kenapa pelampung punggung berdampak lebih baik dibanding pelampung batang, rupanya pelampung punggung mempunyai karakteristik dan kelebihan pada proses pembelajaran nya. 
Kemudian pada saat wawancara (tanya jawab) dengan siswa atau dengan sempel penelitian, mereka mengungkapkan secara langsung bahwa pelampung punggung lebih nyaman digunakan dibanding pelampung batang dan mereka begitu antusias pada saat pembelajaran.

Karakteristik dan kelebihan yang dimiliki oleh pelampung punggung diantaranya:

1. Adanya tali yang bisa diikat kebadan, sehingga pelampung tetap berada pada posisinya.

2. Busa dari bahannya sangat tebal dan bagus sehingga tidak mudah cepat rusak, serta penggunaan nya pun tidak menyulitkan pemakai atau pengguna saat melakukan gerakan tangan ataupun koordinasi, bahkan siswa atau sampel yang memakainya mengungkapkan bahwa alat itu begitu nyaman untuk dipakai.

3. Kemudian mudah dibeli di toko-toko olahraga terdekat serta harganya relatif murah.

Pelampung batang juga memiliki kelebihan tersendiri yaitu:

1. Fleksibel dan unik juga bisa direkatkan dibadan akan tetapi penggunaan nya kurang baik apabila digunakan pada renang gaya bebas karena seringkali berpindah atau tidak berada tetap pada posisi yang di inginkan, seringkali siswa atau sampel pada penelitian mengeluh merasa tidak nyaman pada saat melakukan gerakan tangan dan koordinasi renang gaya bebas.

2. pelampung batang mudah sekali robek atau rusak, lama kelamaan dalam penggunaan nya bisa membuat pelampung batang tidak utuh seperti awal mula membeli karena pelampung batang bisa saja rusak setelah kita pakai secara terus menerus tanpa kita sadari.

3. Pelampung batang harganya lebih mahal dan tidak mudah ditemukan di toko-toko olahraga biasa.

Berdasarkan hasil penelitian, dapat diketahui bahwa terdapat perbedaan antara pelampung batang dan pelampung punggung terhadap keterampilan renang gaya bebas. Mean kelompok pelampung punggung lebih besar dari mean kelompok pelampung batang. Dari kedua alat bantu tersebut yang paling efektif, aman dan nyaman adalah pelampung punggung. dengan begitu pembelajaran renang gaya bebas dengan bantuan pelampung punggung lebih baik dan cocok untuk diterapkan pada pembelajaran berenang gaya bebas khususnya tingkat pemula dibandingkan pembelajaran berenang dengan bantuan Pelampung batang.

Sesuai dengan tujuan penelitian yaitu untuk mengetahui perbandingan pelampung batang dan pelampung punggung terhadap keterampilan renang gaya bebas maka diketahui bahwa ada pengaruh yang signifikan dari pelampung punggung terhadap keterampilan renang gaya bebas. Media memiliki multi makna, baik dilihat secara terbatas maupun secara luas. Munculnya berbagai macam definisi disebabkan adanya perbedaan dalam sudut pandang, 
maksud, dan tujuannya. AECT (Association for Education and Communicatian Technology) memaknai media sebagai segala bentuk yang dimanfaatkan dalam proses penyaluran informasi (Ermawan Susanto, 2011). Manfaat yang dapat diambil dari penggunaan media menurut Oemar Hamalik adalah media dapat membangkitkan motivasi dan pengaruh psikologis bagi peserta didik. Efektifitas proses pembelajaran juga akan terlaksana bila memanfaatkan media pembelajaran (Herka Maya Jatmika, 2014).

Berdasarkan penelitian yang telah dilakukan pada atlet putra SGC Aquatic Club diketahui bahwa alat bantu pelampung punggung dapat meningkatkan hasil kecepatan renang 50 meter gaya bebas atlet putra SGC Aquatic Club, hal ini dikarenakan alat bantu pelampung batang dapat mempermudah atlet untuk membantu meningkatkan kecepatan renang 50 meter gaya bebas.( Toussaint HM,\& Beek PJ, 2011).

\section{KESIMPULAN}

Berdasarkan pengolahan dan analisis data yang diperoleh dari tes keterampilan renang gaya bebas, maka penulis sampaikan kesimpulan dari pelaksanaan penelitian mengenai Perbandingan Pelampung Batang Dan Pelampung Punggung Terhadap Keterampilan Renang Gaya bebas di rizky swimming club, berdasarkan analisis data tersebut maka penulis menarik kesimpulan sebagai berikut:

1. Penggunaan Pelampung batang memeberikan pengaruh terhadap keterampilan renang gaya bebas.

2. Penggunaan Pelampung punggung memeberikan pengaruh terhadap keterampilan renang gaya bebas.

3. Pelampung punggung lebih memberikan pengaruh signifikan terhadap keterampilan renang gaya bebas dibandingkan dengan pelampung batang di rizky Swimming Club.

\section{Limitasi}

Limitasi atau kelemahan pada penelitian terletak pada proses penelitian. Peneliti menyadari bahwa dalam suatu penelitian pasti terjadi banyak kendala dan hambatan. Salah satu factor yang menjadi kendala dan hambatan dalam penelitian ini adalah sarana berupa pelampung punggung dan pelampung batang yang di gunakan secara bergantian, kemudia waktu dan tempat penelitian yang bisa digunakan kolam di bagi menjadi 2 karena kolam yang di gunakan adalah kolam renang umum. 


\section{Rekomendasi}

Bagi para peneliti selanjutnya berkaitan dengan penelitian yang telah dilakukan dalam mengembangkan media alat bantu terhadap keterampilan renang gaya bebas, masih diperlukan penelitian - penelitian lanjutan baik bersifat pengembangan maupun kedalamannya. Oleh karena itu, rekomendasi yang disampaikan bagi peneliti selanjutnya adalah sebagai berikut: 1 . Penelitian yang dilakukan ini, ruang lingkupnya masih terbatas pada siswa rizky swimming $c l u b$. Oleh karena itu masih terbuka untuk dilakukan penelitian dengan mengambil sampel dari siswa yang berada di daerah perkotaan atau di daerah lainnya. 2. Ruang lingkup penelitian ini hanya pada tingkat club, sehingga masih terbuka untuk diadakan penelitian lanjutan yang dihubungkan dengan tingkat pendidikan mulai dari SD, SMP atau SMA.

\section{DAFTAR PUSTAKA}

Aisya husein,mengenal olahraga renang,(Jakarta.pt balai pustaka,2012).h.18.

Elly puji astutik," implementasi kebijakan kepala sekolah tentang pembelajaran renang di smp negeri 1 cerme kabupaten gresik"jurnal kebijakan dan pengembangan pendidikan, volume 2,nomor 1,januari 2014.hal.2

Ermawan Susanto, loc.cit h.36- 452011

Fx.sugiyanto, "keefektifan urutan pembelajaran keterampilan gerak renang"Cakrawala Pendidikan, Juni 2011, Th. XXX, No. 2. hal.8.

Herka Maya Jatmika, "Pemanfaatan Media Visual dalam Menunjang Pembelajaran Pendidikan Jasmani di Sekolah Dasar” Jurnal Pendidikan Jasmani Indonesia, Volume 3, No. 1, 2007.

Mark Young. The complete beginners guide to swimming : professional guidance and support to help you throught every stage of learning how to swim, (educate and learn publishing,2016).h.8

Mukhammadi hamsa,"survey minat siswa kela 153 । VIII di smpn1 bangil dalam mengikuti ekstra kurikuler renang”jurnal olahraga dan kesehatan,volume 3,nomor 3,tahun 2015,hal.2

Mukhammadi hamsa,"survey minat siswa dalam mengikuti ekstrakurikuler renang" jurnal pendidikan olahraga dan kesehatan,volume 03,nomor 03,tahun 2015,h.2

Sugiyono, Metodologi enelitian, (Bandung : Cipta Karya), h. 1072012

Sugiyono, Metode Penelitian Pendidikan Pendekatan, Kuantitatif, Kualitatif, dan R\&D, (Bandung : Alfabeta), h. 1142014

Tejo nurseto, "Membuat Media Yang Menarik", (jurnal ekonomi \& pendidikan, volume 8 nomo1, april 2011) hal.2

Toussaint HM, Beek PJ. Biomechanics of competitive front crawl swimming. Sport Med 2011; 13:8- 24 . 
Sony Hasmarita

Vol. 3 No. 2, Oktober 2021, pp. 144-154 